\title{
Use of Coal Waste as Fine Aggregates in Concrete Paving Blocks
}

\author{
Cassiano Rossi dos Santos, Juarez Ramos do Amaral Filho, Rejane Maria Candiota Tubino, \\ Ivo André Homrich Schneider \\ Federal University of Rio Grande do Sul_UFRGS, Post Graduate Programme in Mining, Metallurgical and Materials \\ Engineering-PPGE3M, Porto Alegre, Brazil \\ Email: ivo.andre@ufrgs.br
}

Received January 18, 2013; revised February 20, 2013; accepted March 6, 2013

Copyright (C) 2013 Cassiano Rossi dos Santos et al. This is an open access article distributed under the Creative Commons Attribution License, which permits unrestricted use, distribution, and reproduction in any medium, provided the original work is properly cited.

\begin{abstract}
The aim of this work was to study the use of coal waste to produce concrete paving blocks. The methodology considered the following steps: sampling of a coal mining waste; gravity separation of the fraction with specific gravity between 2.4 and 2.8; comminution of the material and particle size analysis; technological characterization of the material and the production of concrete paving blocks. The results showed that the coal waste considered in this work can be used to replace conventional sand as a fine aggregate for concrete paving blocks. This practice can collaborate in a cleaner coal production.
\end{abstract}

Keywords: Coal Waste; Recycling; Environment; Concrete

\section{Introduction}

The commercial coal production in the southern region of Brazil (comprising the Paraná, Santa Catarina, and Rio Grande do Sul states) has been occuring since the beginning of the twentieth century. Specifically in the Santa Catarina State, the production occurs at the "Irapuá", "Bonito", and, mainly, "Barro Branco" seams. These Gondwanic coals are classified for the major part as a highvolatile bituminous in rank. The thickness of the "Barro Branco" seam ranges from 1.66 to $2.27 \mathrm{~m}$, with an average value of $1.80 \mathrm{~m}$. However, net clean coal thickness is reduced to $0.47-1.48 \mathrm{~m}$, due to the alternating layers of impure coal (shaley coal), carbonaceous shale, siltstone, and sandstones (Figure 1). Pyrite lenses, sometimes several centimeters thick, are also common [1].

Currently, the run-of-mine coal (ROM) is gravimetrically concentrated and almost entirely used for electricity generation. Due to the geological characteristics, large amounts of solid wastes are generated. It is estimated that more than 300 millions tonnes of coal waste exists in the south of Brazil, generating environmental impacts and economic costs. Regarding the Santa Catarina Coalfields, about $60 \%-65 \%$ of the ROM coal is discharged at dump deposits as waste [2]. These wastes can lead to the formation of acid mine drainage (AMD), a source of ground and surface water pollution [3].

Through gravity concentration processes of this coal wastes it is possible to produce three output streams: 1) a low specific gravity material (relative density $<2.4$ ) and more carbonaceous waste composed by shaley coal and carbonaceous shale; 2) an intermediated material $(2.4<$ relative density $<2.8$ ) composed mainly by siltstone and sandstone; and 3) a high specific gravity material (relative density $>2.8$ ) that is rich in pyrite. Presently, there has been some initiatives in Brazil to reprocess some coal wastes deposits with the purpose of recover part of the carbonaceous materials for energy production and, alternatively, to concentrate the pyrite for sulphuric acid production. However, still remains the intermediate density material, which represents $40 \%-50 \%$ in mass of the coal waste deposit and could be considered as a geomaterial for possible use in civil construction and agriculture [2].

A further serious problem is that the productive chain of civil engineering uses huge amounts of raw materials. In recent years, rapid development has led to an increased demand for river sand, which is largely used as a fine aggregate for construction. The extraction of sand from river bed and river bank may cause adverse affects on the environment, like river bank erosion, river bed degradation, and deterioration of river water quality. This 


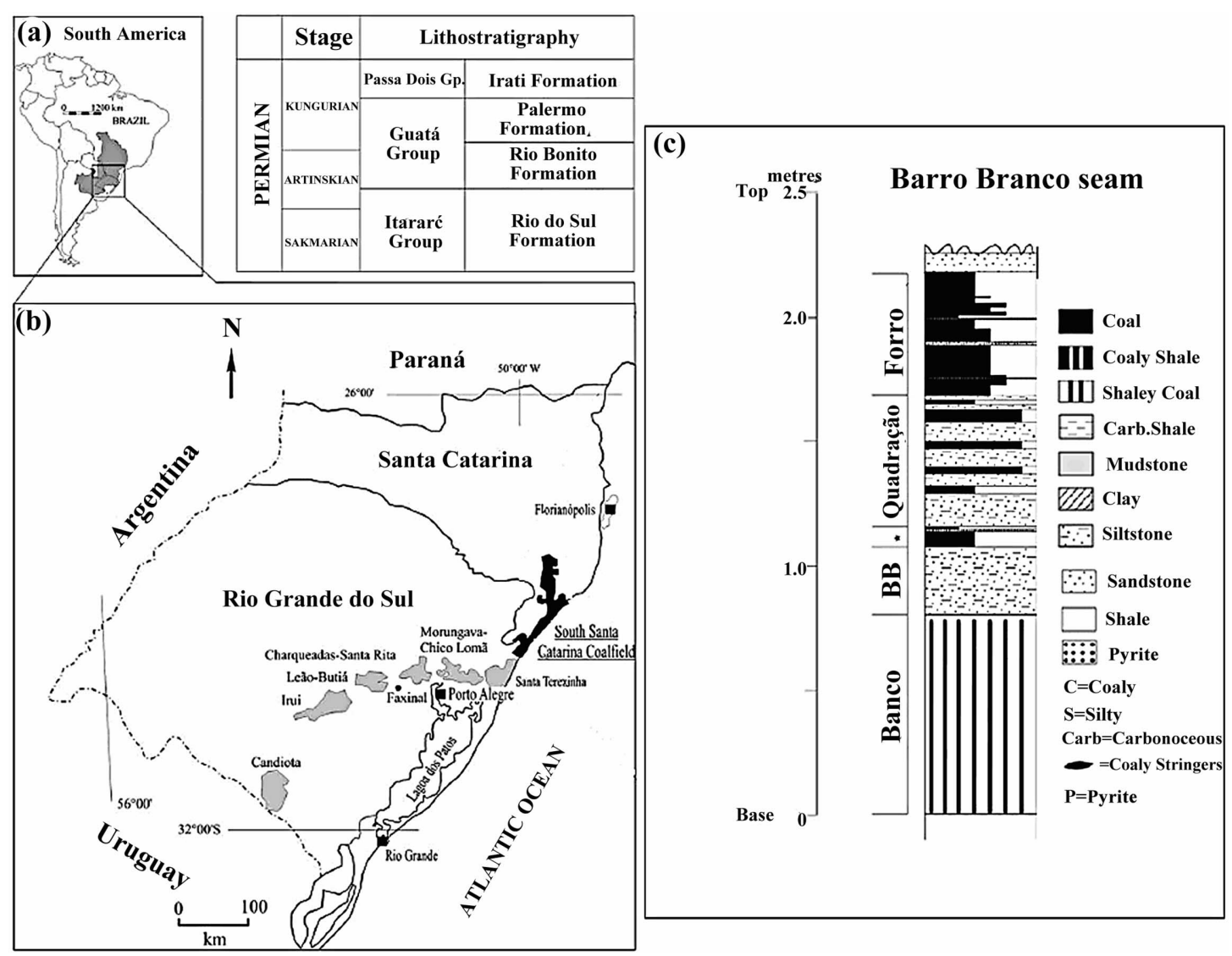

Figure 1. (a) Location of the southern Paraná Basin, Brazil; (b) Distribution of major coalfields in Rio Grande do Sul and Santa Catarina States; (c) Transect showing lithological profiles of the Barro Branco seam [1].

subject has been of concern in Brazil and other countries [4-6].

For example, segmented paving blocks are utilized worldwide and can be used in a large range of applications. The conventional source of fine aggregates for paving blocks are river sand or, alternatively, artificial sand by crushing rocks [7]. However, previous research has shown that it is also possible to use some wastes to produce concrete paving blocks: for example, gasification residues [8], crushed clay bricks [9], and ceramic tile production wastes [10].

Thus, the aim of this work was to study the use of coal waste as fine aggregates to produce concrete blocks for paving. The article briefly evaluates the main technical and environmental parameters that are involved and focused on the recycling part of the coal waste. The present study was undertaken from a scientific standpoint part of the effort to develop an effective coal cleaning process route focused on mitigating pollution problems associated with coal wastes worldwide.

\section{Experimental}

The coal waste was collected from the dump deposit of the "Verdinho Mine", Santa Catarina State-Brazil, which extracts the "Barro Branco" seam. The material was submitted to a laboratory dense medium separation processing that aimed at obtaining a fraction with relative density between 2.4 and 2.8 [11]. This fraction was crushed in a roller mill and sieved to reach a similar size particle distribution of river sand, which is commonly used for paving block production in Brazil. The quartz river sand was obtained from Jacuí River, Rio Grande do Sul State -Brazil. Technological characterization of both materials included particle size distribution, specific weight measurements, visual observation in a petrographic magnifying lens, and mineral phase determination by x-ray diffraction. Elemental analyses of the fine aggregates were carried out by x-ray fluorescence (for $\mathrm{Si}, \mathrm{Fe}, \mathrm{Al}, \mathrm{Ca}, \mathrm{K}$ ) and high temperature decomposition in a CHNS analyzer (for $\mathrm{C}, \mathrm{H}, \mathrm{N}$, and $\mathrm{S}$ ). The main characteristics of both materials are resumed in Table 1.

The concrete paving blocks were produced in a vertical shaft concrete mixer. The reference trace used 5.36 $\mathrm{kg}$ of cement, $6.26 \mathrm{~kg}$ of coarse basaltic aggregate, 14.18 $\mathrm{kg}$ of river sand aggregate, and a water/cement ratio of 0.39 . The coal waste was used as a substitute for river sand aggregate, considering the following volumetric levels of substitution: $0 \%, 25 \%, 50 \%, 75 \%$, and $100 \%$. 
Table 1. Properties of the conventional quartz sand aggregate and the coal waste aggregate.

\begin{tabular}{|c|c|c|}
\hline Property & Conventional quartz sand aggregate & Coal waste aggregate \\
\hline \multicolumn{3}{|l|}{ Particle size (mm) } \\
\hline Size distribution & 0.15 to 4.0 & 0.15 to 4.0 \\
\hline D90 & 2.0 & 3.0 \\
\hline D50 & 0.4 & 1.0 \\
\hline D10 & 0.15 & 0.15 \\
\hline \multicolumn{3}{|l|}{ Density $\left(\mathrm{kg} / \mathrm{dm}^{3}\right)$} \\
\hline Real & 2.6 & 2.3 \\
\hline Apparent & 1.6 & 1.3 \\
\hline Particle shape & Rounded and sub-rounded & Angular \\
\hline Color & Yellowish & Grayish \\
\hline Mineralogical composition & Quartz- $\mathrm{SiO}_{2}$ (major mineral phase) & $\begin{array}{c}\text { Quartz- } \mathrm{SiO}_{2} \text { (major mineral phase), } \\
\text { Kaolinite- }-\mathrm{Al}_{4}(\mathrm{OH})_{8}\left(\mathrm{Si}_{4} \mathrm{O}_{10}\right), \\
\text { Illite- }\left(\mathrm{K}, \mathrm{H}_{3} \mathrm{O}\right)(\mathrm{Al}, \mathrm{Mg}, \mathrm{Fe})_{2}\left(\mathrm{Si}, \mathrm{Al}_{4} \mathrm{O}_{10}\left[(\mathrm{OH})_{2},\left(\mathrm{H}_{2} \mathrm{O}\right)\right]\right. \\
\text { Gypsum- }-\mathrm{CaSO}_{4} \cdot 2 \mathrm{H}_{2} \mathrm{O} .\end{array}$ \\
\hline \multicolumn{3}{|l|}{ Elemental composition (\%) } \\
\hline $\mathrm{C}$ & ND & 2.6 \\
\hline $\mathrm{H}$ & ND & 0.8 \\
\hline $\mathrm{N}$ & ND & 0.1 \\
\hline $\mathrm{S}$ & ND & 1.9 \\
\hline $\mathrm{Si}$ & 63.7 & 47.0 \\
\hline $\mathrm{Fe}$ & 1.0 & 7.5 \\
\hline $\mathrm{Al}$ & 1.7 & 14.0 \\
\hline $\mathrm{Mn}$ & 0.03 & 0.2 \\
\hline $\mathrm{Ca}$ & 0.4 & 4.2 \\
\hline $\mathrm{K}$ & 3.1 & 5.5 \\
\hline
\end{tabular}

For each level of substitution, the water/cement ratio was reestablished to provide the same consistency of concrete [12]. The concrete pieces were molded in a manual press machine with a production capacity of six blocks per cycle. The blocks were molded in the "unipaver" shape with the following dimensions: $22.5 \mathrm{~cm}$ length, $12.0 \mathrm{~cm}$ width, and $8 \mathrm{~cm}$ height.

The technological characterization of the paving blocks included the resistance to compression (at 7, 28, and 90 days), abrasion resistance, water absorption, and colorimetric parameters (at 28 days) [13]. Compression strength, abrasion resistance, and water absorption were carried out in accordance, respectively, to Brazilian Standard Procedures NBR 9780 [14], NBR 12042 [15], and NBR 9778 [16]. Color measurements of the concrete blocks were recorded by reflectance spectra obtained using a MINOLTA CM-2600D spectrophotometer with an integrations sphere associated with an ultraviolet filter. The illuminant D65, which simulates daylight and the standard observer at $10^{\circ}$ were chosen. At the beginning of the experiment, the calibration was done with two reference points, the zero and the white standard. The color parameters $\mathrm{a}^{*}, \mathrm{~b}^{*}$, and $\mathrm{L}^{*}$ that corresponded to the uniform color space CIELAB were obtained directly from the apparatus [17]. Within the uniform space CIELAB, two color coordinates, $\mathrm{a}^{*}$ and $\mathrm{b}^{*}$, as well as a psychometric index of lightness, $\mathrm{L}^{*}$, are defined. a ${ }^{*}$ takes positive values for reddish colors and negative values for the greenish ones, whereas $b^{*}$ takes positive values for yellowish colors and negative values for the bluish ones. $\mathrm{L}^{*}$ presents an approximate measurement of luminosity; according to this property each color can be considered as equivalent to a member of the grey scale, ranging between black and white, taking values within the range of 0 - 100. All measurements were carried out in 6 samples $(n=6)$, and the average and standard deviation was calculated. The statistical technique used to evaluate the differences between averages was the Analysis of Variance (ANOVA), considering a significance level of $5 \%$.

Finally, the acid-generation potential of the raw waste, of the coal waste fine aggregates, and of the paving blocks at 28 days was conducted by the traditional method of accounting for acids and bases (ABA) [18]. The objective was to determine the balance between the minerals that produce acidity (acidity potential-AP) and the minerals which consume acidity (neutralization potential-NP). The net neutralization potential (NNP) was calculated from the difference between NP and AP. A sam- 
Table 2. Properties of the concrete blocks for paving considering different levels of substitution of river sand by coal waste aggregate.

\begin{tabular}{|c|c|c|c|c|c|}
\hline \multirow{2}{*}{ Property } & \multicolumn{5}{|c|}{ Substitution of river sand aggregate by coal waste aggregate } \\
\hline & $0 \%$ & $25 \%$ & $50 \%$ & $75 \%$ & $100 \%$ \\
\hline Water/cement ratio & 0.35 & 0.37 & 0.39 & 0.43 & 0.44 \\
\hline $\begin{array}{c}\text { Compressive strength }(\mathrm{MPa}) \\
7 \text { days } \\
28 \text { days } \\
90 \text { days } \\
\end{array}$ & $\begin{array}{l}28.1 \pm 2.8^{\mathrm{a}} \\
39.5 \pm 2.9^{\mathrm{a}} \\
40.7 \pm 0.3^{\mathrm{a}}\end{array}$ & $\begin{array}{l}33.0 \pm 3.4^{\mathrm{b}} \\
37.6 \pm 1.6^{\mathrm{a}} \\
36.2 \pm 5.2^{\mathrm{b}}\end{array}$ & $\begin{array}{l}34.2 \pm 1.3^{\mathrm{b}} \\
36.6 \pm 1.4^{\mathrm{a}} \\
34.1 \pm 4.4^{\mathrm{b}}\end{array}$ & $\begin{array}{l}28.3 \pm 1.6^{\mathrm{a}} \\
31.2 \pm 2.7^{\mathrm{b}} \\
29.0 \pm 3.8^{\mathrm{c}}\end{array}$ & $\begin{array}{l}24.8 \pm 4.6^{\mathrm{a}} \\
27.3 \pm 3.1^{\mathrm{b}} \\
27.2 \pm 4.8^{\mathrm{c}}\end{array}$ \\
\hline $\begin{array}{l}\text { Abrasion resistance }(\mathrm{mm}) \\
28 \text { days }\end{array}$ & $6.6 \pm 0.0^{\mathrm{a}}$ & $7.5 \pm 1.3^{\mathrm{a}}$ & $7.9 \pm 0.0^{\mathrm{a}}$ & $8.1 \pm 0.5^{\mathrm{a}}$ & $11.44 \pm 3.0^{\mathrm{b}}$ \\
\hline $\begin{array}{l}\text { Water absorption }(\%) \\
28 \text { days }\end{array}$ & $4.9 \pm 0.0^{\mathrm{a}}$ & $5.3 \pm 0.1^{\mathrm{a}}$ & $5.4 \pm 0.0^{\mathrm{a}}$ & $6.9 \pm 0.6^{\mathrm{b}}$ & $8.0 \pm 0.8^{\mathrm{c}}$ \\
\hline $\begin{array}{c}\text { Colorimetric properties } \\
28 \text { days } \\
\mathrm{L}^{*} \\
\mathrm{a}^{*} \\
\mathrm{~b}^{*}\end{array}$ & $\begin{array}{c}57.5 \pm 2.7^{\mathrm{a}} \\
-0.1 \pm 0.2^{\mathrm{a}} \\
7.4 \pm 1.4^{\mathrm{a}}\end{array}$ & $\begin{array}{c}55.4 \pm 5.3^{\mathrm{a}} \\
0.3 \pm 0.5^{\mathrm{b}} \\
6.2 \pm 1.8^{\mathrm{a}}\end{array}$ & $\begin{array}{c}52.7 \pm 4.1^{\mathrm{a}} \\
0.6 \pm 0.3^{\mathrm{b}} \\
7.6 \pm 1.5^{\mathrm{a}}\end{array}$ & $\begin{array}{c}53.2 \pm 3.3^{\mathrm{a}} \\
0.4 \pm 0.2^{\mathrm{b}} \\
7.8 \pm 1.6^{\mathrm{a}}\end{array}$ & $\begin{array}{l}53.1 \pm 3.0^{\mathrm{a}} \\
0.4 \pm 0.1^{\mathrm{b}} \\
6.4 \pm 0.6^{\mathrm{a}}\end{array}$ \\
\hline $\begin{array}{l}\text { Mass of fine aggregates of coal waste } \\
\text { consumed per area of pavement }\left(\mathrm{kg} / \mathrm{m}^{2}\right)\end{array}$ & 0.0 & 12.1 & 24.2 & 36.4 & 48.5 \\
\hline
\end{tabular}

Average \pm standard deviation. Values with the same letters compared horizontally do not differ significantly from each other.

Table 3. Acid generation prediction results of the raw waste, coal waste fine aggregate and the concrete paving blocks with $0 \%, 25 \%$, and $50 \%$ of substitution of river sand by coal waste aggregate.

\begin{tabular}{cccccc}
\hline & & & \multicolumn{3}{c}{ Concrete paving blocks } \\
\cline { 4 - 6 } Parameter & Raw waste & Coal waste aggregate & $\begin{array}{c}0 \% \\
\text { Substitution }\end{array}$ & $\begin{array}{c}25 \% \\
\text { Substitution }\end{array}$ & $\begin{array}{c}50 \% \\
\text { Substitution }\end{array}$ \\
\hline Total S (\%) & 7.0 & 1.9 & 0.5 & 0.4 & 0.9 \\
$\mathrm{AP}\left(\mathrm{kg} \mathrm{CaCO}_{3} / \mathrm{t}\right)$ & 218.8 & 60.8 & 15.7 & 12.2 & 27.5 \\
$\mathrm{NP}\left(\mathrm{kg} \mathrm{CaCO}_{3} / \mathrm{t}\right)$ & 0.0 & 0.0 & 241.0 & 430.0 & 488.2 \\
$\mathrm{NNP}$ & -218.8 & -60.8 & 225.3 & 417.8 & 460.7 \\
Formation of AMD & Yes & Yes & No & No & No \\
\hline
\end{tabular}

ple is classified as acid forming when it has NNP values less than $-20 \mathrm{~kg} \mathrm{CaCO}_{3} / \mathrm{t}$ and as non-acid forming when it has NNP values greater than $+20 \mathrm{~kg} \mathrm{CaCO}_{3} / \mathrm{t}$. Samples are classified as uncertain when their values range from -20 to $+20 \mathrm{~kg} \mathrm{CaCO}_{3} / \mathrm{t}$.

\section{Results and Discussion}

The mineral fine aggregates produced from the coal waste have quartz as their major crystalline phase. The presence of kaolin, illite, and gypsum was also detected. The particles are angular in shape, due to the rock fragmentation procedure. With regard to the presence of sulfur, the concentration in the fine aggregate was determined as $1.9 \%$. This element is considered harmful for concretes, and most international standards recommend that the amount of sulfates and sulfides in aggregates for concrete production should not exceed the value of $1 \%$ [19]. Concerning the materials used in this work, the fine aggregates produced from coal tailings should be applied in levels of substitution of river sand of no more than $50 \%$.

Table 2 shows the main technological properties of concrete blocks for paving, while considering the different levels of substitution. It can be observed that the concrete block produced with levels of substitution of $25 \%$ and $50 \%$, at 28 days, statistically presents similar behavior of the reference blocks in terms of compressive resistance, abrasion resistance, and water absorption. In terms of the compression resistance, at 28 and 90 days the blocks attained, or are very close, to the value of $35 \mathrm{MPa}$ which had been established by the Brazilian Legislation [13]. The colorimetric parameters demonstrate that the paving blocks produced with coal waste aggregates are imperceptibly darker (lower value of $\mathrm{L}^{*}$ ) when compared with the paving blocks produced with the conventional aggregate (Figure 2).

With regard to the acid generation (Table 3), the material collected from the coal waste deposit presents a 


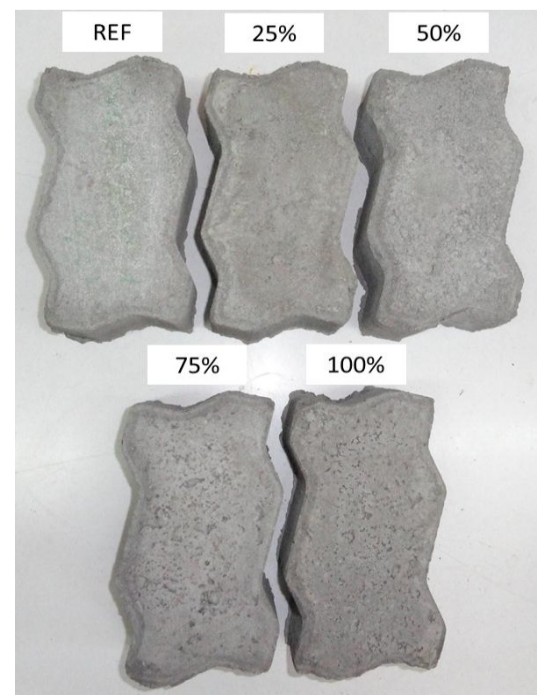

Figure 2. Concrete paving blocks produced with varied levels of substitution of river sand by coal waste aggregate.

high acid generation potential, with a sulfur content of $7.0 \%$, AP of $218.8 \mathrm{~kg} \mathrm{CaCO}_{3} / \mathrm{t}$, NP of $0.0 \mathrm{~kg} \mathrm{CaCO}_{3} / \mathrm{t}$, and NNP of $-218.8 \mathrm{~kg} \mathrm{CaCO}_{3} / \mathrm{t}$. The fraction used for fine aggregate production, with a density between 2.4 and 2.8 , exhibited a reduced acid generation potential, with a sulfur content of $1.9 \%$, AP of $60.8 \mathrm{~kg} \mathrm{CaCO}_{3} / \mathrm{t}$, NP of 0.0 $\mathrm{kg} \mathrm{CaCO}_{3} / \mathrm{t}$, and NNP of $-60.8 \mathrm{~kg} \mathrm{CaCO}_{3} / \mathrm{t}$. The paving blocks produced with $25 \%$ of substitution of river sand by coal waste aggregate presented an S content of $0.4 \%$, AP of $12.2 \mathrm{~kg} \mathrm{CaCO}_{3} / \mathrm{t}$, NP of $430.0 \mathrm{~kg} \mathrm{CaCO} / / \mathrm{t}$, and $\mathrm{NNP}$ of $417.8 \mathrm{~kg} \mathrm{CaCO}_{3} / \mathrm{t}$. These results showed that the manufacture of paving block provided an alkaline environment and prevented acid generation.

With a safe level of substitution of $25 \%$, the demand by coal waste aggregate was estimated to be $12.1 \mathrm{~kg}$ per $\mathrm{m}^{2}$ of paved area. Considering a run-of-mine coal production of a typical Brazilian underground mine of $40,000 \mathrm{t}$ per month, $60 \%$ of the material discharged as waste, and $50 \%$ of this fraction separated between the relative densities of 2.4 and 2.8 , it is possible to produce about 12,000 $\mathrm{t}$ of fine aggregates, which is sufficient to attend a paved area of about $1 \mathrm{~km}^{2}$.

Finally, it should be considered that many coal producers and coal consumer companies in the world are working to avoid the environmental impacts of the coal production chain [20]. The same effort has been carried out in the carboniferous region of Santa Catarina-Brazil, by means of the industries, government, and research institutions, which are engaged to recover all the pollution provided by decades of coal exploration. Many has been developed to recover the degraded areas [21] and to treat the acid mine drainage [3]. However, we consider that part of the solution is to provide a useful destination to the coal mining tailings $[20,22,23]$, considering the prin- ciples of recycling, sustainable development, and integrated mine tailings management $[20,24,25]$.

\section{Conclusion}

The results showed that it was possible to process the coal waste from the carboniferous region of Santa Catarina-Brazil-and obtain a recycled fine aggregate that can be used in civil construction. Concrete blocks for paving produced with $25 \%$ and $50 \%$ of recycled coal waste in substitution of river sand presented satisfactory results in terms of mechanical strength. The use of coal waste as a fine aggregate for concrete block paving manufacture presents technical viability and environmental benefits. This practice can collaborate in clean coal production and enable socioeconomic development within the regional context. The demand by sand deposits can be minimized and a part of coal tailings can be used, reducing the volume in coal waste deposits. We believe that this procedure can be applied to minimize the environmental problems in coal production in Brazil and other parts of the world.

\section{Acknowledgements}

The authors are grateful for the financial support extended by FINEP, CAPES, CNPq, and the Brazilian Coal Network for this research.

\section{REFERENCES}

[1] W. Kalkreuth, M. Holz, A, Mexias, M. Balbinot, J. Levandowski, J. Willett, R. Finkelman and H. Burger, "Depositional Setting, Petrology and Chemistry of Permian Coals from the Paraná Basin: 2. South Santa Catarina Coalfield, Brazil," International Journal of Coal Geology, Vol. 84, No. 3-4, 2010, pp. 213-236. doi:10.1016/j.coal.2010.08.008

[2] J. R. Amaral Filho, I. A. H. Schneider, R. M. C. Tubino, I. A. S. Brum, G. Miltzarek, C. H. Sampaio and C. H. Schneider, "Characterization of a Coal Tailing Deposit for Zero Waste Mine in the Brazilian Coal Field of Santa Catarina," In: Ch. Wolkersdorfer and A. Freund, Eds., Mine Water \& Innovative Thinking, CBU Press, Sydney, 2010, pp. 639-643.

[3] R. D. R. Silva and J. Rubio, "Treatment of Acid Mine Drainage (AMD) from Coal Mines in South Brazil," International Journal of Coal Preparation and Utilization, Vol. 29, No. 4, 2009, pp. 192-202. doi:10.1080/19392690903066045

[4] E. L. Santo and L. E. Sánchez, "GIS Applied to Determine Environmental Impacts Indicators Made by Sand Mining in Floodplains in Southeasterrn Brazil," Environmental Geology, Vol. 41, No. 6, 2002, pp. 628-637. doi:10.1007/s002540100441

[5] M. Sandecki, "Aggregate Mining in River Systems," California Geology, Vol. 42, No. 4, 1989, pp. 88-94. 
[6] Ministry of Natural Resources and Environment, Department of Irrigation and Drainage Malaysia, "River Sand Mining Management Guideline," Kuala Lumpur, 2009, p. 85.

[7] American Concrete Institute-ACI, "Aggregates for Concrete," Education Bulletin E1-07, Farmington Hills, 2007, p. 29.

[8] E. Holt and P. Raivio, "Use of Gasification Residues in Compacted Concrete Paving Blocks," Cement and Concrete Research, Vol. 36, No. 3, 2006. pp. 441-448. doi:10.1016/j.cemconres.2005.09.013

[9] C. S. Poon and D. Chan, "Paving Blocks Made with Recycled Concrete Aggregate and Crushed Clay Brick," Construction and Building Materials, Vol. 20, No. 8, pp. 569-577. doi:10.1016/j.conbuildmat.2005.01.044

[10] S. D. Wattanasiriwech, A. Saiton and S. Wattanasiriwech, "Paving Blocks from Ceramic Tile Production Waste," Journal of Cleaner Production, Vol. 17, No. 18, 2009, pp. 1663-1668. doi:10.1016/j.jclepro.2009.08.008

[11] J. W. Leonard, "Coal Preparation," 5th Edition, Society for Mining, Metallurgy, and Exploration, Inc., Littleton, 1991.

[12] P. K. Mehta and P. J. M. Monteiro, "Concrete: Structure, Properties, and Materials," 2nd Edition, Prentice-Hall, Englewood Cliffs, 1993.

[13] ABNT-Associação Brasileira de Normas Técnicas, NBR 9781, "Peças de Concreto Para Pavimentação-Especificação,” Rio de Janeiro, 1987.

[14] ABNT-Associação Brasileira de Normas Técnicas, NBR 9780, "Peças de Concreto Para Pavimentação. Determinação da Resistência à Compressão-Método de Ensaio," Rio de Janeiro, 1987.

[15] ABNT-Associação Brasileira de Normas Técnicas, NBR 12042, "Materiais Inorgânicos-Determinação do Desgaste por Abrasão-Método de Ensaio," Rio de Janeiro, 1992.

[16] ABNT-Associação Brasileira de Normas Técnicas, NBR 9778, "Argamassa e Concreto Endurecidos-Determinação da Absorção de Água, Índice de Vazios e Massa Específica-Método de Ensaio,” Rio de Janeiro, 2005.

[17] CIE, "Recommendations on Uniform Color Spaces, Color-
Difference Equations, Psychometric Color Terms," Bureau Central de la CIE, Viena, 1978.

[18] Environmental Protection Agency, "Acid Mine Drainage Prediction," EPA 530-R-94-036, Technical Document, 1994.

[19] C. H. Mattus and T. M. Gilliam, "A Literature Review of Mixed Waste Components: Sensitives and Effects upon Solidification/Stabilization in Cement-based Matrices," Oak Ridge National Laboratory, Martin Marietta Energy Systems, Inc., 1994.

[20] L. Haibin and L. Zhenling, "Recycling Utilization Patterns of Coal Mining Waste in China," Resources, Conservation and Recycling, Vol. 54, No. 12, 2010, pp. 1331-1340. doi:10.1016/j.resconrec.2010.05.005

[21] G. Milioli, "Mining, Environment, and Development in South Santa Catarina, Brazil. Non-Governmental Organization 'Terra Verde' and Its Ideas for Sustainability," Environments, Vol. 33, No. 1, 2005, pp. 25-40.

[22] K. M. Skarzynska, "Reuse of Coal Mining Wastes in Civil Engineering-Part 2: Utilization of Minestone," Waste Management, Vol. 15, No. 2, 1995, pp. 83-126. doi:10.1016/0956-053X(95)00008-N

[23] V. G. Lemeshev, I. K. Gubin, Y. A. Savel'ev, D. V. Tumanov and D. O. Lemeshev, "Utilization of Coal-Mining Waste in the Production of Building Ceramic Materials," Glass and Ceramics, Vol. 61, No. 9-10, 2004, pp. 308311. doi:10.1023/B:GLAC.0000048698.58664.97

[24] M. Benzaazoua, B. Bussière, I. Demers, M. Aubertin, E. Fried and A. Blier, "Integrated Mine Tailings Management by Combining Environmental Desulphurization and Cemented Paste Backfill: Application to Mine Doyon, Quebec, Canada," Minerals Engineering, Vol. 21, No. 4, 2008, pp. 330-340. doi:10.1016/j.mineng.2007.11.012

[25] A. H. Hesketh, J. L. Broadhurst and S. T. L. Harrison, "Mitigating the Generation of Acid Mine Drainage from Copper Sulfide Tailings Impoundments in Perpetuity: A Case Study for an Integrated Management Strategy," Minerals Engineering, Vol. 23, No. 3, 2010, pp. 225-229. doi:10.1016/j.mineng.2009.09.020 